\title{
Live pig markets are hotspots for spread of African swine fever virus in Nigeria
}

\author{
Adeyinka Adedeji ${ }^{1}$, Rebecca Atai ${ }^{1}$, Helen E. Gyang ${ }^{1}$, Panzam Gambo ${ }^{2}$, Maimuna A. \\ Habib $^{2}$, R. Weka ${ }^{1}$, Muwanika V.B. ${ }^{3}$, Charles Masembe ${ }^{3}$, and Pam Luka ${ }^{1}$ \\ ${ }^{1}$ National Veterinary Research Institute \\ ${ }^{2}$ Federal Ministry of Agriculture and Rural Development \\ ${ }^{3}$ Makerere University College of Agricultural and Environmental Sciences
}

January 18, 2022

\begin{abstract}
Livestock trading through live animal markets are potential pathways for the introduction and spread of economically important pathogens like the African swine fever virus (ASFV) to new areas in several countries. Due to the high demand for live pigs in Nigeria both for restocking and slaughter, live pigs are sold at designated live pig markets (LPM) in the country. This involves movement of pigs over long distances. Despite, reports of ASF outbreaks following restocking of pigs bought from LPMs, there is paucity of information on the role of LPMs in the epidemiology of ASF. In this study, data and pig samples (whole blood, sera, tissue) were collected from 4 selected LPMs in Nigeria (Dawaki, Katsit, Numan \& Pandam) between 2019 and 2020. Samples were analysed by polymerase chain reaction (PCR) and Enzyme-linked Immunosorbent Assay (ELISA). Four genes of ASFV positive samples were characterized to identify the circulating genotypes. Results revealed trade activities involving transportation of pigs from these selected markets to 42 major cities and towns in thirteen (13) States of Nigeria. PCR results revealed an overall ASF prevalence of $10.77 \%$ (66/613). ASFV was confirmed by PCR in all the selected LPMs with a prevalence rate of $3.13 \%-23.81 \%$. The phylogeny revealed genotype I and serogroup 4 based on the $p 72$ protein that encodes the B646L gene and the EP402R gene encoding the CD2V. While sequence analysis of CVR of B602L gene revealed 8 tetrameric repeats variants, six of which have never been reported in Nigeria. Analysis of sera samples recorded a seroprevalence of $6.9 \%(16 / 217)$ within the study period. Findings from this study show that LPM are hotspots and channels for transmission and continuous spread of ASFV in Nigeria. Therefore, for ASF to be controlled in Nigeria, disease surveillance and regulation at LPMs are critical.
\end{abstract}

\section{Introduction}

Trading livestock through live animal markets is an important part of the economy of many developing countries (Fèvre et al., 2006; Leslie et al., 2015; Perry et al., 2005). Demand for live pigs is high in pigproducing areas of Nigeria, because these animals play a vital role in the culture and tradition of the people as they are used for celebrations and festivities (Fasina et al., 2010). Pig marketing in Nigeria consists largely of live animal sales which are acquired from multiple sources either directly from farmers at farm gates or fellow traders at live pig markets (LPMs) (Ajala \& Adesehinwa, 2008; Weka et al., 2021). Hence, LPMs are hubs for the congregation of animals from a wide range of locations some of which are reporting outbreak diseases. In addition, poor biosecurity practices, limited government regulation, and poor infrastructure enhance the ease of disease spread at these markets. Likewise, the trading and movement of sick pigs have been identified as a crucial pathway to the spread of transboundary diseases like African swine fever (ASF) in endemic countries such as Nigeria (Costard et al., 2013; Olugasa \& Ijagbone, 2007). Pig husbandry system in Nigeria is differentiated into mostly free-roaming/extensive, semi-intensive and intensive pig production systems in pig producing areas in Northern Nigeria and intensive commercial/ communal pig estates in 
Southern Nigeria (Bourn et al., 1994, Ajala et al., 2006; Saka et al., 2010; Nwanta et al., 2011). In Nigeria, farmers restock their farms from LPMs and there have been reports of ASF outbreaks in pig farms following introduction of pigs from these markets. Also, due to high demand and need for better prices by farmers and traders, pigs reared in the northern parts of Nigeria are transported to southern parts of the country, the majority of such transactions is via LPMs. ASF is a lethal transboundary disease of pigs caused by the ASF virus (ASFV) which is the only member of the genus Asfivirus and familyAsfarviridae (Dixon et al., 2020). The disease is endemic and restricted to countries in sub-Saharan Africa, but due to the highly transboundary nature of ASFV, the disease has spread to domestic and wild pigs in Europe, Asia, and Oceania (Penrith, 2020; Sauter-Louis et al., 2020). Genetic typing of the virus is based on characterization of the p72 capsid protein of $B 646 L$, the full length of the p54 of $E 183 L$, and further differentiation using the central variable region of B602L (Bastos et al., 2003; Gallardo et al., 2009). Based on the p72 p rotein capsid, 24 genotypes of ASFV have been identified, most of which are restricted to East and Southern Africa (Bastos et al., 2003; Quembo et al., 2018). Genotyping methods are important tools for tracing the origin of ASFVs and quickly differentiate or related virus strains during ASF outbreaks (Malogolovkin et al., 2015a). The serogroupingidentification method can be used to further discriminate ASFV strains. Based on this method, 8 ASFV serogroups have been identified based on the EP402R gene encoding the CD2V protein (Malogolovkin et al., 2015a). ASF was first introduced into Nigeria in 1997 via the trading of pigs by communities along the international border with the Benin Republic (Odemuyiwa et al., 2000). Thereafter, the disease spread to other pig-producing areas of the country through livestock trading routes (Fasina et al., 2010; Luka et al., 2016; Owolodun, et al., 2010a). ASFV genotype I was the only circulating genotype in Nigeria, until recently when genotype II was introduced into the country (Adedeji et al., 2021). Despite the importance of live pig markets (LPM) in the pig value chain in Nigeria, there are no extensive studies on the role of these markets in the epidemiology of ASF in Nigeria (Fasina et al., 2010; Luka et al., 2016; Owolodun, Bastos, et al., 2010). Though, previous studies have detected ASFV and swine influenza virus in a live pig market in Nigeria (Dennis et al., 2019; Luka et al., 2016; Meseko et al., 2014). However, these studies involved only one pig market with limited information on activities and pig movements in and out of the market. Studies in Nigeria have revealed that live bird markets play an important role in the ecology and epidemiology of Avian influenza in Nigeria (Coker et al., 2014; Fusaro et al., 2009; Sulaiman et al., 2021). Similarly, it has been reported that livestock farmers in Nigeria sell their animals through live animal markets to mitigate economic losses during disease outbreaks (Bolajoko et al., 2019). This further emphasizes the importance of live animal markets in the epidemiology of transboundary livestock diseases in Nigeria. This study assessed the role of LPMs as hotspots for transmission and continuous spread of ASFV in Nigeria

\section{Materials and methods}

Study area: Nigeria is located in West Africa, bordered by the Benin Republic to the west, the Niger Republic to the north, Cameroun to the east, and the Atlantic Ocean to the south. The country is divided into 36 States and the Federal Capital Territory (FCT) Abuja. The 36 States are further divided into Local government areas (LGA) with a total of 774 LGAs. Pigs are reared in 30 States of the country. Nigeria has two seasonal periods, the rainy season which is from April to October, and the dry season from November to March. The common breeds of pigs in Nigeria are the Iberian type Nigerian Indigenous Pig (NIP) which is usually black or pied, others are exotic breeds including, Large White, Landrace, Duroc, Hampshire, and their crossbreeds (Fadiga et al, 2013).

Selection and description of live pig markets: Organized LPMs are common in northern parts of Nigeria, while in the southern part of Nigeria, pigs are sold live at farm gates or as processed pork at stores. Due to limited information on the LPM operation in Nigeria, selection of LPM sites were done purposively based on information from pig farmers, easy access, literature search, logistics, visit to LPM, the network of distribution, security challenges, and the number of live pigs traded at markets visited. Hence, four (4) live pig markets were purposefully selected, all located in Northern Nigeria namely: Katsit pig market (also called Kafanchan pig market) in Zagon Kataf LGA of Kaduna State, Pandam pig market in Qua Pan LGA, and Dawaki pig market in Kanke LGA both located in Plateau State and Numan pig market in Numan LGA of Adamawa State (Fig 1). Katsit pig market is located on latitude N $9^{0} .34255$ and Longitude E $8^{0} .164936$ 
at the outskirts of Kafanchan, Kaduna State. It is the largest LPM in Nigeria, Table 1), it is once a week market with trading activities taking place on Thursdays only. Located within the premises of the Katsit pig market is a slaughter slab where pigs bought within the market are slaughtered and sold to traders and the surrounding communities. The second market is Pandam pig market located on latitude $\mathrm{N} 9^{0} .52519$ and longitude $\mathrm{E} 8^{0} .50510$, it is also a once in week market with sales of pigs taking place on Mondays (Table 1). There is a slaughter point $500 \mathrm{~m}$ to the market. The third market is Dawaki pig market, which is located on latitude N9.2625956 deg and longitude E $9.3401578 \mathrm{deg}$. Apart from pigs, other animals sold at the Dawaki pig market including sheep, goats, chickens, and dogs. The Dawaki pig market holds weekly on Thursdays. The slaughter point at Dawaki pig market is located directly behind the perimeter fence of the market with an access point for free movement of butchers and traders. The fourth market is the Numan Pig market located in Numan LGA of Adamawa State, the market holds on Tuesdays with GPS co-ordinates N $09^{0} .27440$ ' E12 .002043'

Table 1: Selected live pig markets located in Nigeria where this study was carried out.

\begin{tabular}{lllll}
\hline Market & Village/LGA & State & Market days & Presence of pig slaughter slab within/by \\
\hline Dawaki Pig market & Dawaki/Kanke & Plateau & Thursdays & Yes \\
Katsit Pig market & Katsit/Zangon/Kataf & Kaduna & Thursdays & Yes \\
Numan Pig Market & Numan/Numan & Adamawa & Tuesdays & No \\
Pandam Pig market & Pandam/Quan Pan & Plateau & Mondays & No \\
\hline
\end{tabular}

Data collection: Data was collected based on key informant interviews of government and pig traders' union officials at the market sites. Data collected were: average weekly population of pigs in the markets. Towns and villages from where pigs are brought into the markets and locations where the pig purchased are transported to. Government regulations in the markets and attached slaughter slabs and the fate of pigs unsold on at the market. Data on the average number of pigs slaughtered at the slabs were also collected.

Field observation: Due to poor records at the selected LPMs, observations of activities of the value chain actors (traders, farmers, transporters) and slaughter slab operators were carried out using a checklist. These include pre-entry inspections of pigs going in and out of the market site, mode of transportation of the pigs, holding facilities at the markets e.g pens, activities of the slaughter slab operators, and access of people and other animals to the market sites. Others include common breeds of pigs at the market, estimated age of pigs brought to the market, sanitation, and hygiene at the market sites. To carry out this aspect of the study, arrival at market sites was from 7 am to 8 am depending on location to maximize observation of activities, sample collections, and travel time back to the laboratory. At least 2 cycles of visits were planned per month for data and sample collection.

Figure 1: Map of Northern part of Nigeria, showing the movement of pigs from towns and villages into the four selected live pigs markets

Figure 2 : Map of Nigeria showing movement and outflows of pigs from four selected pig markets to various destinations in the country

Sample size determination and collections: From April 2019- Feb 2020, October-November, 2020 samples were collected at the Dawaki, Katsit, Numan, and Pandam pig markets in Nigeria. With a population of 7 million pigs, the minimum recommended sample size for such a population using a confidence level of $95 \%$ and a margin of error of $5 \%$ gives a calculated sample size of 384 (Dohoo et al., 2009). The samples were collected using a convenient sampling method, based on the cooperation of the pig traders and slaughter slab operators. The samples collected were whole blood, tissue, and sera samples. $5 \mathrm{mls}$ of blood in heparinized and plain sample bottles were collected from pigs at LPMs and their slaughter slabs. Tissue samples (liver, spleen, and mesenteric nodes) were collected in labelled sample bottles from all pigs slaughtered at the slaughter slabs within the premises of the LPMs. Criteria for sample collection at the slaughter slab was pigs bought at LPMs, pigs from external sources were excluded. Both apparently healthy and sick pigs 
were sampled. Sample collection was disrupted between March 2020 and September 2020 due to COVID-19 lockdown restrictions in Nigeria.

Detection of African swine fever antibodies : Sera samples collected were analyzed using commercially available ID Screen ASF Indirect kit (IDVet, Grabels, France) specific for the presence of antibodies against ASFV p32, p62, and $p$ 72 proteins according to the manufacturer's instructions.

Detection of African swine fever virus. Total DNA was extracted from whole blood and homogenized tissue samples using the Qiagen Mini kit (Qiagen, Hilden Germany) following the manufacturer's protocol. A $257 \mathrm{bp}$ region corresponding to the C-terminal region of the $B 646$ gene encoding the p 72 major capsid protein was amplified using the diagnostic primers PPA1 and PPA2 as previously reported to confirm the presence of the ASFV genome (Aguero et al., 2003).

\section{ASFV genotyping, serogrouping and CVR sequence analysis}

Representative ASFV positive samples from the 4 selected LPMs were selected for molecular characterization targeting four regions of the virus. The regions were the C-terminal end of the $B 646 L$ gene encoding the $p 72$ protein, the full length of $E 183 \mathrm{~L}$ gene encoding $p 54$ protein, central variable region (CVR) within the B602L and CD2v protein encoding the EP402R gene (Bastos et al., 2003; Gallardo et al., 2009; Malogolovkin et al., 2015b). ASFV sequences were generated commercially by Macrogen Inc. (Netherlands Europe) and LGC Genomic (Germany). The raw sequence data were assembled using Staden Package (http://staden.sourceforge.net/) and multiple alignments were performed using the CLUSTALX algorithm implemented in MEGA X (Kumar et al., 2018). Sequences for four gene segments of ASFV were compared to available sequences in the GenBank using the Basic Local Alignment Search Tool (https://blast.ncbi.nlm.nih.gov/Blast) with default settings. MEGA X was used for phylogenic analysis to a Neighbor-joining tree inferred using the Maximum Composite Likelihood method for 172 protein with data resampled 1,000 times in the bootstrap method. For the 154 protein encoded in E183Lgene, a Minimum Evolution method tree was inferred using the Maximum Composite Likelihood method and data resampled 1,000 times in the bootstrap method (Kumar et al., 2018). The CD2v protein sequences were inferred using Neighbor-joining method and data resampled 1,000 times in the bootstrap method. Sequences of ASFV genotypes and serogroups were retrieved from the Genbank for the construction of the phylogenetic trees for both p72, p54 and CD2v protein genes. The tandem repeat sequences (TRS) of CVR (B602L gene) from this study were translated to protein sequences using ExPASy (https ://web.expas y.org/translate/) with default software settings. The translated amino acid tetramers were matched with previously reported codes (Achenbach et al., 2017; Nix et al., 2006). ASFV TRS from this study were compared with 21 TRS of CVR previously reported in Nigeria and other West African countries. Sequences were deposited into GenBank with the following accession numbers: OL692379- OL692391 (p72 gene), OL692397-OL692406 (p54), OL692410-OL692419 (B602L gene) and OL780773- OL780778 (CD2v gene).

\section{Data analysis and mapping of pig movement}

Results of data and analyzed samples collected were tabulated, maps of pig movements were generated to show the inflows and outflows of pigs at the 4 selected LPMs in Nigeria.

\section{Ethics approval}

This study was approved by the National Veterinary Research Institute Animal Ethics Committee Vom, Nigeria (AEC/03/26/16).

\section{Results}

\section{Data on weekly population and destinations of pigs at the four selected live pig markets}

A total of 34 visits were carried out to the four selected LPMs for data and sample collection within 13 months period. The common breeds at the four selected live pig markets visited were the crossbreed of Nigeria Indigenous Pig (NIP), Large White, Landrace and Duroc with an age range from 6 months- 5 years. Weekly population of pigs at the selected LPMs was as follows: Katsit (3,000-6,000 pigs) (Fig1A, Table 2 ), 
Pandam (1,500-3000 pigs) (Table 2, Fig 3B), Dawaki (400-500 pigs), and Numan pig markets (1,000- 1,500). The pig population on a market day depends on the season of the year, there are more pigs during the dry season compared to the rainy season. Overall, it is estimated that 500,000 -700,000 pigs transit through these markets yearly. Data collected based on the interview of the pig market officials shows that the pigs are also brought to the market and transported to several locations (Fig 1-2). Pigs bought from Katsit pig market are supplied to 18 towns or cities in 13 States of Nigeria, (Table 2, Fig 2). Pigs are brought into Katsit pig market from several towns or villages in Kaduna (14), Niger (4), Nasarawa (3), and Plateau (2) States (Table 2, Fig 1). While pigs at the Pandam market are sourced from villages or towns in Plateau State (20) and Nasarawa State (4). Interestingly, pigs from Pandam pig market are also transported to the Katsit pig market. Furthermore, pigs sold at Dawaki pig market are mostly sourced from villages and towns in Bauchi (2) and Plateau (8) States, and transported to 5 States in Nigeria (Table 2). Live pigs traded at the Numan pig market are sourced from towns and villages in Adamawa (9), Gombe (7), and Taraba (2) States as well as the Republic of Cameroon. From the Numan pig market, the pigs are transported to 5 States of Nigeria (Table 2, Fig 2). Based on the data collected at the slaughter slabs within or closed to the LPMs, averagely, 15-40 pigs are slaughtered at Katsit, while 4-10 pigs are slaughtered at Dawaki, Numan, and Pandam Markets. The number of pigs slaughtered is dependent on the season of the year and disease outbreak. Postmortem meat inspection is usually carried out by a veterinary assistant with emphasis on zoonotic diseases like tuberculosis and porcine cysticercosis which are partially or wholly condemned for destruction.

Table 2: Live pigs markets in Nigeria and the locations where pigs are sourced and destinations where they are transported to.

\begin{tabular}{|c|c|c|c|c|}
\hline Live Pig Market & $\begin{array}{l}\text { Weekly pig } \\
\text { population }\end{array}$ & $\begin{array}{l}\text { States and towns } \\
\text { where Pigs are } \\
\text { sourced }\end{array}$ & $\begin{array}{l}\text { State and towns } \\
\text { where they are } \\
\text { transported to after } \\
\text { being purchased }\end{array}$ & $\begin{array}{l}\text { Average number of } \\
\text { pigs slaughtered at } \\
\text { Slab per Market day }\end{array}$ \\
\hline $\begin{array}{l}\text { Katsit pig Market, } \\
\text { Kaduna State }\end{array}$ & $\begin{array}{l}\text { Dry Season: } \\
4,000-6,000 \text { Rainy } \\
\text { Season: } 3,000-3,500\end{array}$ & $\begin{array}{l}\text { Plateau (Jos, } \\
\text { Pandam) Nasarawa } \\
\text { (Keffi, Makera, } \\
\text { Garaku Assakio) } \\
\text { Kaduna (Kachia, } \\
\text { Kaduna town, Birin } \\
\text { Gwari, Fadan } \\
\text { Karshi, Gwantu, } \\
\text { Kudumi, Kagoro, } \\
\text { Sabon Gida, Gidan } \\
\text { Waya, Kufana, } \\
\text { Kwoi, Kachia, } \\
\text { Zagon Kataf, } \\
\text { Manchok, Zaria), } \\
\text { Niger (Kuchi, } \\
\text { Zazagga, Guni, } \\
\text { Sarkin Pawa) }\end{array}$ & $\begin{array}{l}\text { Enugu (Enugu, } \\
\text { Obolla-afor) Benue } \\
\text { (Makurdi, Gboko, } \\
\text { Otukpo, Eke) Edo } \\
\text { (Benin, Auchi), } \\
\text { Enugu (Obolla-afor, } \\
\text { Enugu) Kaduna } \\
\text { (Kaduna) } \\
\text { Cross-river ( } \\
\text { Calabar) Akwa } \\
\text { Ibom (Uyo) Rivers } \\
\text { (Port Harcourt) } \\
\text { Nasarawa (Assakio) } \\
\text { Delta (Asaba, } \\
\text { Warri) Lagos } \\
\text { (Badagry) Anambra } \\
\text { (Onitsha) Abuja } \\
\text { Bayelsa (Yenagoa) }\end{array}$ & 15-40 pigs \\
\hline
\end{tabular}




\begin{tabular}{|c|c|c|c|c|}
\hline Live Pig Market & $\begin{array}{l}\text { Weekly pig } \\
\text { population }\end{array}$ & $\begin{array}{l}\text { States and towns } \\
\text { where Pigs are } \\
\text { sourced }\end{array}$ & $\begin{array}{l}\text { State and towns } \\
\text { where they are } \\
\text { transported to after } \\
\text { being purchased }\end{array}$ & $\begin{array}{l}\text { Average number of } \\
\text { pigs slaughtered at } \\
\text { Slab per Market day }\end{array}$ \\
\hline $\begin{array}{l}\text { Pandam Pig Market } \\
\text { Plateau State }\end{array}$ & $\begin{array}{l}\text { Dry Season: } \\
2,500-3000 \text { Rainy } \\
\text { Season: } 1,500-2,000\end{array}$ & $\begin{array}{l}\text { Plateau (Mangu, } \\
\text { Langtang, Mabudi, } \\
\text { Bokkos, Shendam, } \\
\text { Panshin, Tunkus, } \\
\text { Zomo, Amper, } \\
\text { Gazum, Pajat, } \\
\text { Kabwir, Shishiri, } \\
\text { Pilgani, Kerang, } \\
\text { Ampang, Kwanpe, } \\
\text { Tashan Sule, } \\
\text { Shishiri, Pil-Gani, } \\
\text { Pajat) Nasaraw } \\
\text { State (Assakio) }\end{array}$ & $\begin{array}{l}\text { Plateau (Jos) } \\
\text { Nassarawa (Lafiya, } \\
\text { Awe, Assakio) } \\
\text { Kaduna (Kaduna, } \\
\text { Kafanchan) Benue } \\
\text { (Makurdi, Oturkpo, } \\
\text { Vandeikya } \\
\text { Cross-River ( } \\
\text { Calabar, Ikom, } \\
\text { Ogoja, Obudu) } \\
\text { Enugu (Enugu, } \\
\text { Obollaofar) Taraba } \\
\text { (Wukari) Kogi } \\
\text { (Lokoja) River } \\
\text { (Port Harcourt, } \\
\text { Bonny) Delta } \\
\text { (Warri) Bayelsa } \\
\text { (Yenagoa) }\end{array}$ & 4-10 pigs \\
\hline $\begin{array}{l}\text { Dawaki Pig Market } \\
\text { Plateau State }\end{array}$ & $400-500$ & $\begin{array}{l}\text { Plateau (Mangu, } \\
\text { Panshin, Amper, } \\
\text { Lantang, Dasham, } \\
\text { Dawaki, Kwal, } \\
\text { Kabwir) Bauchi } \\
\text { (Tafawa Balewa, } \\
\text { Bogoro) }\end{array}$ & $\begin{array}{l}\text { Cross River (Ikom, } \\
\text { Ogoja, Obudu, } \\
\text { Obubura) Plateau } \\
\text { (Jos, Pandam, } \\
\text { Langtang, } \\
\text { Shendam), } \\
\text { Nasarawa (Assakio) } \\
\text { Benue (Makurdi) } \\
\text { Enugu (Enugu) }\end{array}$ & $4-10$ pigs \\
\hline $\begin{array}{l}\text { Numan Pig Market } \\
\text { Adamawa State }\end{array}$ & $1,000-1,500$ & $\begin{array}{l}\text { Adamawa (Numan, } \\
\text { Michika, Bazza, } \\
\text { Watu, Banganje, } \\
\text { Dong, Guyuk, } \\
\text { Kwaddai, } \\
\text { Ngbalang) Gombe } \\
\text { (Kalungo, tal, Todi, } \\
\text { Banganje, Ture, } \\
\text { Pobauli, Kalaring) } \\
\text { Taraba State (Zing, } \\
\text { Mayo-lope) } \\
\text { Cameroon }\end{array}$ & $\begin{array}{l}\text { Cross River (Ikom, } \\
\text { Ogoja, Biase, } \\
\text { Calabar) Benue } \\
\text { State (Zaki Biam, } \\
\text { Vandeikya) Delta } \\
\text { State (Warri) } \\
\text { Ebonyi State } \\
\text { (Abakaliki) } \\
\text { Adamawa State } \\
\text { (Yola) }\end{array}$ & \\
\hline
\end{tabular}

Table 3: Monthly distribution of samples collected at the four selected live pig markets in Nigeria and the results of samples analyzed by the polymerase chain reaction

\begin{tabular}{lllll}
\hline Month \& Year & Tissue samples & Blood samples & Total samples & Samples positive by PCR \\
\hline April 2019 & 5 & 9 & 14 & 5 \\
May, 2019 & 17 & 55 & 72 & 14
\end{tabular}




\begin{tabular}{lllll}
\hline Month \& Year & Tissue samples & Blood samples & Total samples & Samples positive by PCR \\
\hline June 2019 & 6 & 0 & 6 & 1 \\
July 2019 & 18 & 11 & 29 & 4 \\
August 2019 & 67 & 54 & 121 & 5 \\
September 2019 & 15 & 9 & 24 & 4 \\
October 2019 & 47 & 36 & 83 & 3 \\
November 2019 & 16 & 12 & 28 & 7 \\
December 2019 & 20 & 14 & 34 & 0 \\
January 2020 & 51 & 32 & 83 & 15 \\
February 2020 & 27 & 19 & 46 & 2 \\
March 2020- Sept 2020 & 0 & 0 & 0 & 0 \\
October 2020 & 39 & 26 & 65 & 10 \\
November 2020 & 27 & 10 & 37 & 0 \\
Total & $\mathbf{3 5 5}$ & $\mathbf{2 5 8}$ & 613 & 66 \\
\hline
\end{tabular}

Patten of trade at live pig markets: Apart from Numan and Katsit pig markets, there are no holding pens in all the 3 other LPMs. Pigs are kept under trees on the bare ground which is not cemented and they tethered to pegs very close to each other (Fig 3A-B). Although at Katsit LPM there is a private withhold facility, within the market, there are no pens. The traders transport their pigs in trucks, vans, and motorcycles to the LPMs. The pigs are collected from different communities or villages close to the markets. Pigs are bought based on physical appearance and size without weighting. There were no preentry antemortem inspections before pigs were allowed into the market' sites. Although, inside the LPMs antemortem inspection is usually carried by traders to rule out porcine cysticercosis by examination of the tongue of pigs before any transaction. All the four pig markets in this study were fenced, but the perimeter fencing of Dawaki and Katsit were partial, free-roaming pigs or dogs were observed at the two markets. Another observation is the washing of transport vehicles within the premises of the markets. Further observation is the slaughtering of moribund pigs in the premises of the market sites (Fig 3D). Other observations include free movement of slaughter slab operators between the slaughter slabs and the market area where live pigs are kept. Pigs are slaughtered on every market day and sales of pork were observed at all live pig market sites. Pigs showing clinical signs suggestive of ASF were observed at three LPMs (Dawaki, Katsit, Pandam) cyanotic skin and ASFV genome was detected by PCR in samples collected from some of these pigs (Fig 3C).

\section{Laboratory results}

\section{ELISA results}

A total of 217 sera samples were analyzed using ID Screen ASF Indirect (IDVet, Grabels, France), with a seroprevalence of $6.9 \%(16 / 217)$, which were as follows: Dawaki $5.6 \%(1 / 18)$, Katsit $4.2 \%(7 / 167)$, Numan $27.3 \%(6 / 22)$ and Pandam 10\% (1/10).

\section{Polymerase Chain Reaction results}

A total of 613 samples were collected comprising 355 tissue and 258 whole blood samples with an overall prevalence of $10.77 \%$ (66/613). Of which, ASFV was detected in $13.52 \%(48 / 355)$ and $6.98 \%(18 / 258)$ of tissue and whole blood samples respectively by PCR (Table 2). Furthermore, the results showed Dawaki live pig market had the highest PCR positive samples of $23.81 \%$ (15/63), followed by Padam $18.18 \%$ (16/88), Katsit market had $8.13 \%(35 / 430)$, and $3.13 \%(1 / 32)$ in Numan pig markets respectively. ASFV was detected by PCR in at least one sample collected during 28 of 34 visits (Table 3 ).

Phylogenetic analysis of B646L, E183L and EP402Rgenes of African swine fever virus detected and sequence in samples collected 
The targeted fragments of the ASFV samples was amplified and sequenced successfully as follows $B 646 L$ (13), E183L (10) and B602L (10) genes. While only 6 ASFV samples were successfully amplified and sequenced for the EP402R. The samples were selected from the LPMs as follows Katsit (8), Dawaki (3), Pandam (1) and Numan (1).

The phylogeny of B646L gene revealed ASFV genotype I was circulating in all the selected LPMs within the study period (Fig 2).Phylogenetic analysis of the E183L ( p54) gene of ASFV revealed that live pig market ASFV sequences clustered with genotype 1a sequences of Nigeria and West African countries (Fig $3)$. Furthermore, the phylogeny of theEP402R (CD2v) gene shows all the ASFV sequences from Nigeria clustered within serogroup 4 alongside isolates from Mali (Fig 5)

\section{Sequence analysis Tandem repeat sequences of CVR (B602L)}

The analysis of TRS of CVR (Table 4) revealed 8 TRS variants namely: Tet-10, Tet-13, Tet-18, Tet-20a, Tet-22, Tet-26, Tet-33 and Tet-41 from samples collected between April 2019 and November 2020. Six of the TRS variants were new and different from previously reported variants reported in Nigeria. The TRS variants were recovered as follows: Dawaki (1), Katsit (6) Numan (1) and Pandam (1). Katsit and Pandam share similar TRS variants (Tet-13) (Table 4), similarly Tet-13 was recovered from Katsit and Pandam LPMs.

Figure 3 : A). Katsit live pig market in Zagon Kataf LGA, Kaduna State Nigeria B). Pandam live pig market in Quan Pan LGA Plateau State, Nigeria. C: A pig with the classical presentation of African Swine Fever in a live pig market in Nigeria. D). Moribund pigs are slaughtered inside a live pig market in Nigeria.

Figure 4: Phylogenetic tree of partial p72 gene nucleotide sequences of Nigeria ASFV samples collected in live pig markets in Nigeria The tree was constructed in MEGA X using the Neighbor joining method with 1,000 bootstrap replicates. The Nigerian ASFV isolates from this study are highlighted with diamond shape (Red for 2019 and blue for 2020)

Figure 5: Phylogenetic tree of partial p54 gene nucleotide sequences of Nigeria ASFV samples collected in live pig markets in Nigeria The tree was constructed in MEGA X using the Minimum-Evolution method with 1,000 bootstrap replicates. The Nigerian ASFV isolates from this study are highlighted with diamond shape (Red for 2019 and blue for 2020)

Figure 6: Maximum Likelihood tree based on the partial amino acid sequence of CD2v protein of the $E P 424 R$ gene of ASFV samples collected in live pig markets in Nigeria. The tree was constructed in MEGA $\mathrm{X}$. The Nigerian ASFV isolates from this study are highlighted with diamond shape (Red for 2019 and blue for 2020). Bootstrap values greater than $75 \%$ are shown

Table 4: CVR profiles of Nigerian ASFV of this study and other selected Other Nigerian ASFV and West Africa

\begin{tabular}{|c|c|c|c|c|c|c|c|}
\hline $\begin{array}{l}\text { Isolate } \\
\text { name }\end{array}$ & $\begin{array}{l}\text { Location } \\
\text { of samples } \\
\text { collection }\end{array}$ & Year & $\begin{array}{l}\text { Source of } \\
\text { inflow or } \\
\text { outflow of } \\
\text { pigs to } \\
\text { markets }\end{array}$ & CVR & $\begin{array}{l}\text { Number of } \\
\text { repeats }\end{array}$ & $\begin{array}{l}\text { Accession } \\
\text { Number }\end{array}$ & Reference \\
\hline $\begin{array}{l}\text { Nig-- } \\
\text { DWK286 }\end{array}$ & $\begin{array}{l}\text { Live pig } \\
\text { market } \\
\text { Dawaki, } \\
\text { Plateau } \\
\text { State }\end{array}$ & 2019 & $\begin{array}{l}\text { Both inflow } \\
\text { and outflow }\end{array}$ & ABNA & 3АAAAACBN & AAACBNAA & ATHBNSAAdAAC \\
\hline
\end{tabular}




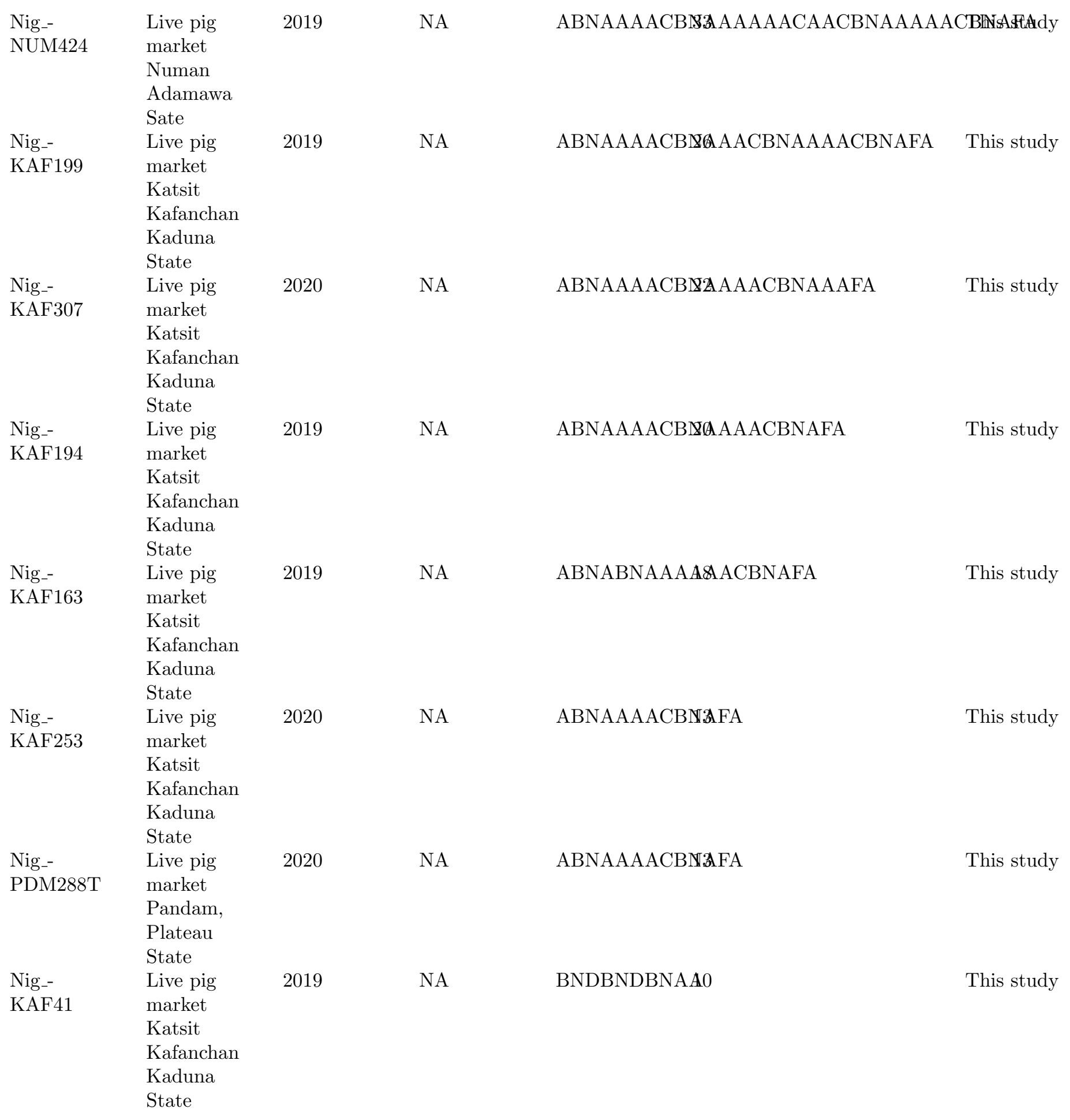




\begin{tabular}{|c|c|c|c|c|c|c|}
\hline $\begin{array}{l}\text { Nig_- } \\
\text { KAF164 }\end{array}$ & $\begin{array}{l}\text { Live pig } \\
\text { market } \\
\text { Katsit } \\
\text { Kafanchan } \\
\text { Kaduna } \\
\text { State }\end{array}$ & 2020 & NA & BNDBNDBNAA0 & & This study \\
\hline $\begin{array}{l}\text { Katsit } \\
\text { fetus } 2\end{array}$ & $\begin{array}{l}\text { Live pig } \\
\text { market } \\
\text { Katsit } \\
\text { Kafanchan } \\
\text { Kaduna } \\
\text { State }\end{array}$ & 2005 & NA & \multicolumn{2}{|c|}{ ABNAAAACBУÄAAACBNAFAQ427185 } & $\begin{array}{l}\text { (Owolodun, } \\
\text {, et al., } \\
2010)\end{array}$ \\
\hline $\begin{array}{l}\text { Nigeria_- } \\
\text { ABD13KPM2_- } \\
\text { A }\end{array}$ & $\begin{array}{l}\text { Live pig } \\
\text {-market } \\
\text { Katsit } \\
\text { Kafanchan } \\
\text { Kaduna } \\
\text { State }\end{array}$ & 2012 & NA & \multicolumn{2}{|c|}{ ABNAAAAACBObABTDBNAFA } & $\begin{array}{l}\text { (Luka et } \\
\text { al., 2016) }\end{array}$ \\
\hline $\begin{array}{l}\text { Nig11_- } \\
\text { KAF_14 }\end{array}$ & $\begin{array}{l}\text { Live pig } \\
\text { market } \\
\text { Katsit } \\
\text { Kafanchan } \\
\text { Kaduna } \\
\text { State }\end{array}$ & 2014 & NA & ABNABNAAAAßCBNA & KT961377 & $\begin{array}{l}\text { (Luka et } \\
\text { al., 2016) }\end{array}$ \\
\hline $\begin{array}{l}\text { Nig13_- } \\
\text { KAF_14 }\end{array}$ & $\begin{array}{l}\text { Live pig } \\
\text { market } \\
\text { Katsit } \\
\text { Kafanchan } \\
\text { Kaduna } \\
\text { State }\end{array}$ & 2014 & NA & ABNABNAAAATACBNAFA & KT961366 & $\begin{array}{l}\text { (Luka et } \\
\text { al., 2016) }\end{array}$ \\
\hline $\begin{array}{l}\text { Nig12_- } \\
\text { KAF_14 }\end{array}$ & $\begin{array}{l}\text { Live pig } \\
\text { market } \\
\text { Katsit } \\
\text { Kafanchan } \\
\text { Kaduna } \\
\text { State }\end{array}$ & 2014 & NA & \multicolumn{3}{|c|}{ 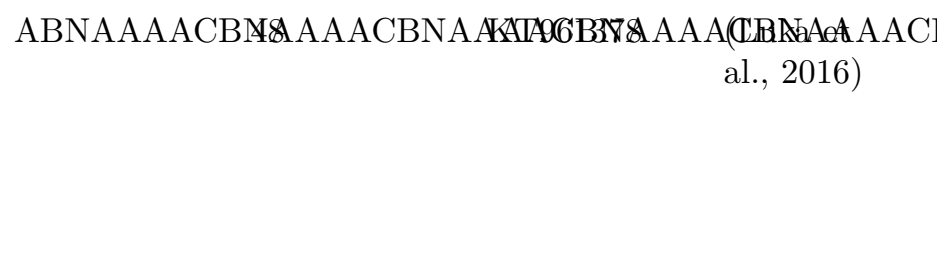 } \\
\hline PL03 & $\begin{array}{l}\text { K-Vom, } \\
\text { Plateau } \\
\text { State } \\
\text { Nigeria }\end{array}$ & 2016 & Inflow & \multicolumn{2}{|l|}{ ABNABNAAAAAHEIBNA } & $\begin{array}{l}\text { Adedeji et al } \\
2021\end{array}$ \\
\hline $\begin{array}{l}\text { Nigeria_- } \\
\text { CDP11SP }\end{array}$ & Delta/Ughelli & 2007 & Outflow & ABNABNAAAA7ACBNAFA & KT150931 & \\
\hline $\begin{array}{l}\text { Nig29_- } \\
\text { LGTT5_- } \\
15\end{array}$ & Plateau/Langt & argig15 & Inflow & ABNAAAACAAACBNAFA & KT961375 & \\
\hline $\begin{array}{l}\text { Nig6_- } \\
\text { JS10_13 }\end{array}$ & Plateau/Jos & 2013 & Inflow & \multicolumn{3}{|c|}{ ABNAAAACBN AAACBNA AKATI6B36AAACBNAAAACI } \\
\hline $\begin{array}{l}\text { NIG_- } \\
\text { BNGBT2 }\end{array}$ & $\begin{array}{l}\text { Benue State } \\
\text { Nigeria }\end{array}$ & 2009 & Outflow & ABNAAAAACBObABTDBN & FIAT150924 & $\begin{array}{l}\text { Luka et al, } \\
2015\end{array}$ \\
\hline
\end{tabular}




\begin{tabular}{|c|c|c|c|c|c|}
\hline $\begin{array}{l}\mathrm{NIG}_{--} \\
\text {ABDPOSASF: }\end{array}$ & $\begin{array}{l}\text { Jos Plateau } \\
\text { State }\end{array}$ & 2011 & Inflow & ABNAAAAACBObABTDBNAFAT150923 & $\begin{array}{l}\text { Luka et al, } \\
2015\end{array}$ \\
\hline \multicolumn{6}{|c|}{$\begin{array}{r}\text { ABDPOSASF5 } \text { State } \\
\text { Nigeria }\end{array}$} \\
\hline $\begin{array}{l}\text { Makurdi } \\
\text { pig }\end{array}$ & $\begin{array}{l}\text { Benue, } \\
\text { Nigeria }\end{array}$ & 2005 & Outflow & ABNAAAACBУAAAAACBNAT427186 & $\begin{array}{l}\text { (Owolodun, } \\
\text { et al., } \\
2010)\end{array}$ \\
\hline Udi pig 1 & $\begin{array}{l}\text { Enugu } \\
\text { State } \\
\text { Nigeria }\end{array}$ & 2003 & Outflow & ABNAAAACBУAAAACBNAAGQA2BI8AFA & $\begin{array}{l}\text { (Owolodun, } \\
\text { Bastos, et } \\
\text { al., 2010) }\end{array}$ \\
\hline OJ pig 1 & Edo & 2006 & Outflow & ABNAAAAACB9AAAACBNAGAQALAIIBNAI & $\begin{array}{l}\text { FAOwolodun, } \\
\text { Bastos, et } \\
\text { al., 2010) }\end{array}$ \\
\hline Nig 01 & Lagos & 2006 & Outflow & AAACBNAAA $\$$ AACBNAAAAAACBNAAA & $\mathrm{AB}$ \\
\hline $\mathrm{CAM} / 89$ & Cameroon & 1989 & Inflow & ABNAAAACBУCAAAACBNAFAF513045 & \\
\hline $\begin{array}{l}\text { IC- } \\
\mathrm{SD} / 2014 / 2\end{array}$ & Ivory & 2014 & NA & ABNAAAAACBObABTDBNAFNH836365 & (Luka et \\
\hline $\begin{array}{l}\mathrm{SP} / 2014 / 3 \\
\text { Ben09/AGL1 }\end{array}$ & $\begin{array}{l}\text { Coast } \\
\text { Benin }\end{array}$ & 2009 & $\mathrm{NA}$ & ABNA A A A ACRМА А A A ACBNAFA & $\begin{array}{l}\text { al., 2016) } \\
\text { (Alkhamis }\end{array}$ \\
\hline DCIUग/ RULL & DCतIIII & 2005 & Nת & 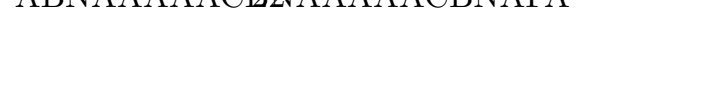 & $\begin{array}{l}\text { et al., } \\
2018)\end{array}$ \\
\hline $\operatorname{Tog} 09 / \mathrm{P} 1$ & Togo & 2009 & NA & ABNAAAAACBATA2\&AAACBNAFA & $\begin{array}{l}\text { (Alkhamis } \\
\text { et al., } \\
\text { 2018) }\end{array}$ \\
\hline
\end{tabular}

\section{Discussion}

This is the first comprehensive study on the possible role of LPMs in spread of ASFV in Nigeria. Field reports revealed that ASF outbreaks occur throughout the year with many unanswered questions on how the ASFV persists and continue to spread in the pig populations in the country. Findings from this study suggest that LPMs in Nigeria may play a key role in the unabated ASF outbreaks in the country. During the duration of this study which was conducted over a period of 13 months involving 34 visits. ASFV was detected by PCR in samples collected during at least one visit in the 4 selected LPMs. In addition, at one sample collected during 28 out of 34 visits was positive and ASFV was also detected in 12 out 13 months that samples were collected within the study period (Table 3). Although, visits to the markets were disrupted by COVID-19 lockdown restrictions in Nigeria between March 2020 and September 2020, however, samples were collected for the first 11 calendar months. The total number of samples collected was 613, with ASFV detected by PCR in $10.72 \%$ (66) of samples collected. In addition, ASFV was detected in $3.13 \%-23.81 \%$ of pig samples collected in all selected live pigs markets. Finding from this study indicates that ASF-infected pigs are sold at all the selected pig markets in Nigeria. This is worrisome because pigs from these markets are supplied to several cities and towns in Nigeria (Fig 2) both for slaughtering and restocking. Previously, ASFV has been detected in Katsit pig market, however, this is the first report of detection of ASFV in Dawaki, Numan, and Pandam LPMs (Luka et al., 2016; Owolodun et al., 2010; Owolodun, Yakubu, et al., 2010b). Phylogenetic analysis of characterized sequences $B 646 \mathrm{~L}$ and $E 183 \mathrm{~L}$ genes selected positive samples collected from the 4 LPMs revealed ASFV genotype I and Ia respectively (Fig $4 \& 5$ ). While, analysis of the sequence CD2v gene revealed Nigerian ASFV samples clustered in serogroup 4 (Fig 6). However, analysis of CVR sequences showed 8 TRS variants were recovered from the markets within the study period (Table 4). Six variants (Tet-10, Tet-13, Tet-18, Tet-26, Tet-33, Tet-41) are being reported for the first time in this study. These findings suggest that live pig markets are the most likely locations to recover the current circulating ASFV TRS variants in Nigeria. In addition, adequate attention and regulation of activities at live pig markets are important in the control of the disease in the country. Previously, 5 TRS variants (Tet-15, Tet-17a, Tet-20a, 20b, Tet-48) were recovered at Katsit market, the same variants were detected in outbreak cases in other parts of the country. Particularly, Tet-20b which was widely circulating in Nigeria between 2009 and 
2015 (Luka et al., 2016; Owolodun, et al., 2010). In addition to TRS variants recovered in this study, 21 variants have now been are identified in Nigeria, 13 variants of which have been recovered from LPMs in the country. The live animal market trade system plays a crucial role in the introduction of pathogens into new areas particularly long-distance disease spread (Martin et al., 2011; Zhou et al., 2015). Likewise, previous studies have described the important role of the live bird market in the epidemiology of avian influenza in Nigeria, but no report on the role of LPMs in the epidemiology of ASF in the country (Coker et al., 2014; Sulaiman et al., 2021). This study has demonstrated that ASFV is circulating in LPMs in Nigeria. These markets are possibly hotspots for the long-distance spread of the virus via the movement of ASF-infected pigs to several locations in the country from LPMs. Though most of the pigs traded in these markets are for slaughter, however, farmers also buy pigs at these markets for restocking on their farms. In addition, unsold pigs are returned to owners' farms after the market day because of the unavailability of withholding facilities at these markets. Such practice further complicates the situations of ASF in Nigeria. It is important to note all the markets where this study was carried out, there is limited government regulation of market operators' activities. The apparent absence of antemortem inspection at market gates, lack of holding pens, close contact of pigs from different locations, and selling of pork within market premises enhances the ease of ASFV spread between pigs at market premises. Other poor biosecurity practices observed were free access to market sites by free-roaming pigs and dogs and unrestricted access of slaughter slab operators. Field reports in Nigeria and previous studies in Zambia have reported outbreaks following the introduction of pigs bought at LPMs (Siamupa et al., 2018; Simulundu et al., 2018). This study also demonstrated the widespread free movement of pigs from surrounding communities to the four live pig markets and the movement of pigs from markets to various destinations in Nigeria (Fig 1 and Fig 2). In total, pigs are sourced from over 70 villages/towns located in 7 States of Nigeria and villages in Cameroon for trading at the market sites (Table 2, Fig 2), while pigs traded at the markets are supplied to 42 towns and cities in 13 States of Nigeria (Table 2, Fig 2). It is interesting to note that all these pig movements are done without movement permits or health certificates issued by the appropriate government agencies. In other countries like Zambia, Indonesia, and China, movement permits or health certificates are required before the movement of pigs between farms, live pig markets, districts, and regions (Gao et al., 2021; Leslie et al., 2016; Siamupa et al., 2018). Movement permits and certificates are important tools to track pig movements and reduce the risk of disease spread, but in Nigeria these movement permits/health certificates were not in use in all the live pig markets selected for this study. Results from this study estimate that nearly 500,000-700,000 pigs transit through these markets yearly, without appropriate restrictions or regulation to mitigate the spread of important transboundary diseases such as ASF. The pigs are transported to live pig markets using motorcycles, cars, buses, trucks, and on foot. The vehicles visit multiple farms, villages or towns, and livestock markets to collect and deliver the pigs to the markets without proper sanitary measures to prevent disease transmission. Also after delivery, the vehicles were washed at market premises leading to possible environmental contamination with the virus.

\section{Conclusion}

The study shows the possible role of LPMs in spread of ASF. Of the samples collected, ASF was detected in $10.77 \%$ (66/613), while seroprevalence was $5.9 \%$. Phylogenetic analysis of characterized samples collected from markets revealed ASFV genotype I. While sequence analysis of CVR within B602L recovered 8 TRS variants, six of which are new. For effective ASF control measures in Nigeria, disease surveillance and strict regulation at live pig markets must be put in place.

\section{Acknowledgments}

This research was funded by the African Union Commission(AURG-II-1-196-2016). The authors acknowledge the staff of the National Veterinary Research Institute Vom and Animal Production and Health Section, International Atomic Energy Agency, Vienna, Austria for their technical assistance. We also acknowledge pig's traders at the live pig markets where this study was carried out.

\section{References}

Achenbach, J. E., Gallardo, C., Nieto-Pelegrín, E., Rivera-Arroyo, B., Degefa-Negi, T., Arias, M., Jenberie, 
S., Mulisa, D. D., Gizaw, D., Gelaye, E., Chibssa, T. R., Belaye, A., Loitsch, A., Forsa, M., Yami, M., Diallo, A., Soler, A., Lamien, C. E., \& Sánchez-Vizcaíno, J. M. (2017). Identification of a New Genotype of African Swine Fever Virus in Domestic Pigs from Ethiopia. Transboundary and Emerging Diseases ,64 (5), 1393-1404. https://doi.org/10.1111/tbed.12511

Adedeji, A. J., Luka, P. D., Atai, R. B., Olubade, T. A., Hambolu, D. A., Ogunleye, M. A., Muwanika, V. B., \& Masembe, C. (2021). First-Time Presence of African Swine Fever Virus Genotype II in Nigeria.Microbiology Resource Announcements , 10 (26). https://doi.org/10.1128/MRA.00350-21

Ajala, M. K., \& Adesehinwa, A. O. K. (n.d.). Analysis of Pig Marketing in Zango Kataf Local Government Area of Kaduna State, Nigeria . 11.

Alkhamis, M. A., Gallardo, C., Jurado, C., Soler, A., Arias, M., \& Sánchez-Vizcaíno, J. M. (2018). Phylodynamics and evolutionary epidemiology of African swine fever p72-CVR genes in Eurasia and Africa.PLOS ONE , 13 (2), e0192565. https://doi.org/10.1371/journal.pone.0192565

Bastos, A. D. S., Penrith, M.-L., Crucière, C., Edrich, J. L., Hutchings, G., Roger, F., Couacy-Hymann, E., \& R.Thomson, G. (2003). Genotyping field strains of African swine fever virus by partial p72 gene characterization. Archives of Virology , 148 (4), 693-706. https://doi.org/10.1007/s00705-002-0946-8

Bolajoko, M. B., Adedeji, A. J., Dashe, G. D., Òsemeke, O. H., \& Luka, P. D. (2019). MOLECULAR EPIDEMIOLOGY AND ECONOMIC IMPACT OF GOAT POX ON SMALL HOLDER SHEEP AND GOATS FARMERS IN NORTH CENTRAL NIGERIA.Small Ruminant Research , 179 , 75-78. https://doi.org/10.1016/j.smallrumres.2019.09.013

Coker, T., Meseko, C., Odaibo, G., \& Olaleye, D. (2014). Circulation of the low pathogenic avian influenza subtype H5N2 virus in ducks at a live bird market in Ibadan, Nigeria. Infectious Diseases of Poverty ,3 (1), 38. https://doi.org/10.1186/2049-9957-3-38

Costard, S., Mur, L., Lubroth, J., Sanchez-Vizcaino, J. M., \& Pfeiffer, D. U. (2013). Epidemiology of African swine fever virus. Virus Research, 173 (1), 191-197. https://doi.org/10.1016/j.virusres.2012.10.030

Dennis, K., Oyiguh, A., \& Dadah, A. J. (2019). SEROPREVALENCE OF SWINE INFLUENZA A VIRUS CIRCULATING IN PIGS FROM SOUTHERN KADUNA, NIGERIA . 14 (3), 4.

Dixon, L. K., Stahl, K., Jori, F., Vial, L., \& Pfeiffer, D. U. (2020). African Swine Fever Epidemiology and Control. Annual Review of Animal Biosciences , 8 (1), 221-246. https://doi.org/10.1146/annurev-animal021419-083741

Fasina, F. O., Shamaki, D., Makinde, A. A., Lombin, L. H., Lazarus, D. D., Rufai, S. A., Adamu, S. S., Agom, D., Pelayo, V., Soler, A., Simón, A., Adedeji, A. J., Yakubu, M. B., Mantip, S., Benshak, A. J., Okeke, I., Anagor, P., Mandeng, D. C., Akanbi, B. O., ... Gallardo, C. (2010). Surveillance for African Swine Fever in Nigeria, 2006-2009: Surveillance for African Swine Fever, Nigeria. Transboundary and Emerging Diseases , no-no. https://doi.org/10.1111/j.1865-1682.2010.01142.x

Fèvre, E. M., Bronsvoort, B. M. de C., Hamilton, K. A., \& Cleaveland, S. (2006). Animal movements and the spread of infectious diseases. Trends in Microbiology , 14 (3), 125-131. https://doi.org/10.1016/j.tim.2006.01.004

Fusaro, A., Joannis, T., Monne, I., Salviato, A., Yakubu, B., Meseko, C., Oladokun, T., Fassina, S., Capua, I., \& Cattoli, G. (2009). Introduction into Nigeria of a Distinct Genotype of Avian Influenza Virus (H5N1). Emerging Infectious Diseases , 15 (3), 445-447. https://doi.org/10.3201/eid1503.081161

Gallardo, C., Mwaengo, D. M., Macharia, J. M., Arias, M., Taracha, E. A., Soler, A., Okoth, E., Martín, E., Kasiti, J., \& Bishop, R. P. (2009). Enhanced discrimination of African swine fever virus isolates through nucleotide sequencing of the p54, p72, and pB602L (CVR) genes. Virus Genes , 38 (1), 85-95. https://doi.org/10.1007/s11262-008-0293-2 
Gao, X., Liu, T., Liu, Y., Xiao, J., \& Wang, H. (2021). Transmission of African swine fever in China Through Legal Trade of Live Pigs.Transboundary and Emerging Diseases , 68 (2), 355-360. https://doi.org/10.1111/tbed.13681

Kumar, S., Stecher, G., Li, M., Knyaz, C., \& Tamura, K. (2018). MEGA X: Molecular Evolutionary Genetics Analysis across Computing Platforms. Molecular Biology and Evolution , 35 (6), 1547-1549. https://doi.org/10.1093/molbev/msy096

Leslie, E. E. C., Christley, R. M., Geong, M., Ward, M. P., \& Toribio, J.-A. L. M. L. (2015). Analysis of pig movements across eastern Indonesia, 2009-2010. Preventive Veterinary Medicine ,118 (4), 293-305. https://doi.org/10.1016/j.prevetmed.2014.12.002

Leslie, E. E. C., Geong, M., Abdurrahman, M., Ward, M. P., \& Toribio, J.-A. L. M. L. (2016). Live pig markets in eastern Indonesia: Trader characteristics, biosecurity and implications for disease spread.Acta Tropica , 155 , 95-103. https://doi.org/10.1016/j.actatropica.2015.12.014

Luka, P. D., Achenbach, J. E., Mwiine, F. N., Lamien, C. E., Shamaki, D., Unger, H., \& Erume, J. (2016). Genetic Characterization of Circulating African Swine Fever Viruses in Nigeria (2007-2015). Transboundary and Emerging Diseases , 64 (5), 1598-1609. https://doi.org/10.1111/tbed.12553

Malogolovkin, A., Burmakina, G., Titov, I., Sereda, A., Gogin, A., Baryshnikova, E., \& Kolbasov, D. (2015a). Comparative Analysis of African Swine Fever Virus Genotypes and Serogroups. Emerging Infectious Diseases , 21 (2), 312-315. https://doi.org/10.3201/eid2102.140649

Malogolovkin, A., Burmakina, G., Titov, I., Sereda, A., Gogin, A., Baryshnikova, E., \& Kolbasov, D. (2015b). Comparative Analysis of African Swine Fever Virus Genotypes and Serogroups. Emerging Infectious Diseases , 21 (2), 312-315. https://doi.org/10.3201/eid2102.140649

Meseko, C. A., Odurinde, O., \& Olaniran, O. (2014). Influenza infections in live pig market, Nigeria. International Journal of Infectious Diseases , 21 , 267. https://doi.org/10.1016/j.ijid.2014.03.975

Nix, R. J., Gallardo, C., Hutchings, G., Blanco, E., \& Dixon, L. K. (2006). Molecular epidemiology of African swine fever virus studied by analysis of four variable genome regions. Archives of Virology ,151 (12), 2475-2494. https://doi.org/10.1007/s00705-006-0794-z

Odemuyiwa, S. O., Adebayo, I. A., Ammerlaan, W., Ajuwape, A. T. P., Alaka, O. O., Oyedele, O. I., Soyelu, K. O., Olaleye, D. O., Otesile, E. B., \& Muller, C. P. (2000). An Outbreak of African Swine Fever in Nigeria: Virus Isolation and Molecular Characterization of the VP72 Gene of a First Isolate from West Africa . 20 (2), 139-142.

Olugasa, B. O., \& Ijagbone, I. F. (2007). Pattern of spread of African swine fever in south-western Nigeria, 1997-2005. Vet Ital ,43, 9.

Owolodun, O. A., Bastos, A. D. S., Antiabong, J. F., Ogedengbe, M. E., Ekong, P. S., \& Yakubu, B. (2010). Molecular characterisation of African swine fever viruses from Nigeria (2003-2006) recovers multiple virus variants and reaffirms CVR epidemiological utility. Virus Genes , 41 (3), 361-368. https://doi.org/10.1007/s11262-009-0444-0

Owolodun, O. A., Yakubu, B., Antiabong, J. F., Ogedengbe, M. E., Luka, P. D., John Audu, B., Ekong, P. S., \& Shamaki, D. (2010a). Spatio-Temporal Dynamics of African Swine Fever Outbreaks in Nigeria, 2002-2007: Dynamics of ASF in Nigeria. Transboundary and Emerging Diseases , 57 (5), 330-339. https://doi.org/10.1111/j.1865-1682.2010.01153.x

Owolodun, O. A., Yakubu, B., Antiabong, J. F., Ogedengbe, M. E., Luka, P. D., John Audu, B., Ekong, P. S., \& Shamaki, D. (2010b). Spatio-Temporal Dynamics of African Swine Fever Outbreaks in Nigeria, 2002-2007: Dynamics of ASF in Nigeria. Transboundary and Emerging Diseases , 57 (5), 330-339. https://doi.org/10.1111/j.1865-1682.2010.01153.x 
Perry, B., Pratt, A. N., Sones, K., \& Stevens, C. (n.d.). An Appropriate Level of Risk: Balancing the Need for Safe Livestock Products with Fair Market Access for the Poor . 83.

Quembo, C. J., Jori, F., Vosloo, W., \& Heath, L. (2018). Genetic characterization of African swine fever virus isolates from soft ticks at the wildlife/domestic interface in Mozambique and identification of a novel genotype. Transboundary and Emerging Diseases ,65 (2), 420-431. https://doi.org/10.1111/tbed.12700

Siamupa, C., Saasa, N., \& Phiri, A. M. (2018). Contribution of market value chain to the control of African swine fever in Zambia.Tropical Animal Health and Production , 50 (1), 177-185. https://doi.org/10.1007/s11250-017-1419-0

Simulundu, E., Chambaro, H. M., Sinkala, Y., Kajihara, M., Ogawa, H., Mori, A., Ndebe, J., Dautu, G., Mataa, L., Lubaba, C. H., Simuntala, C., Fandamu, P., Simuunza, M., Pandey, G. S., Samui, K. L., Misinzo, G., Takada, A., \& Mweene, A. S. (2018). Co-circulation of multiple genotypes of African swine fever viruses among domestic pigs in Zambia (2013-2015). Transboundary and Emerging Diseases , 65 (1), 114-122. https://doi.org/10.1111/tbed.12635

Sulaiman, L., Shittu, I., Fusaro, A., Inuwa, B., Zecchin, B., Gado, D., Schivo, A., Bianco, A., Laleye, A., Gobbo, F., Vakuru, C., Joannis, T., Monne, I., \& Meseko, C. (2021). Live Bird Markets in Nigeria: A Potential Reservoir for H9N2 Avian Influenza Viruses. Viruses ,13 (8), 1445. https://doi.org/10.3390/v13081445

Weka, R., Bwala, D., Adedeji, Y., Ifende, I., Davou, A., Ogo, N., \& Luka, P. (2021). Tracing the Domestic Pigs in Africa. In Tracing the Domestic Pig [Working Title] . IntechOpen. https://doi.org/10.5772/intechopen.95077 


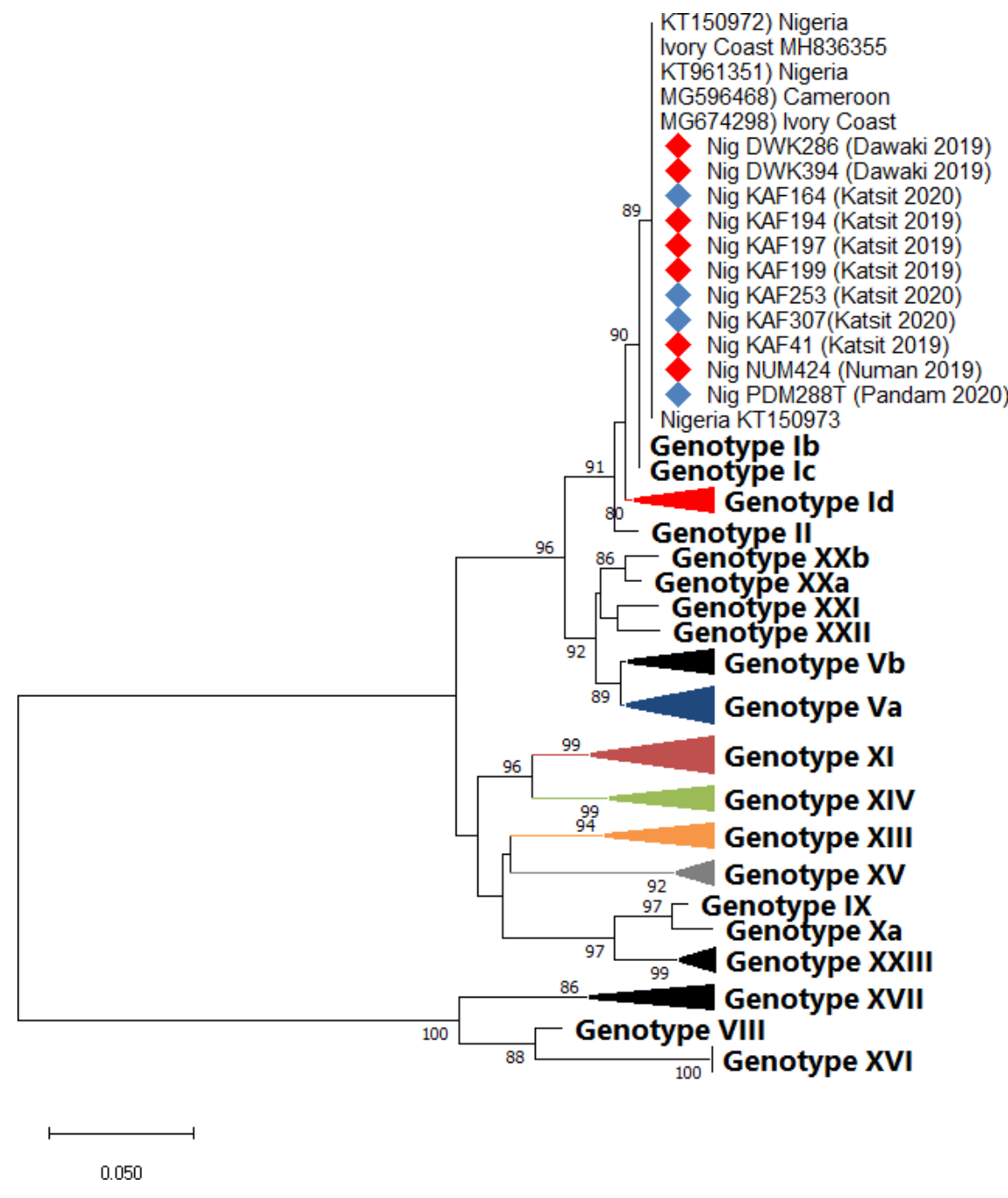



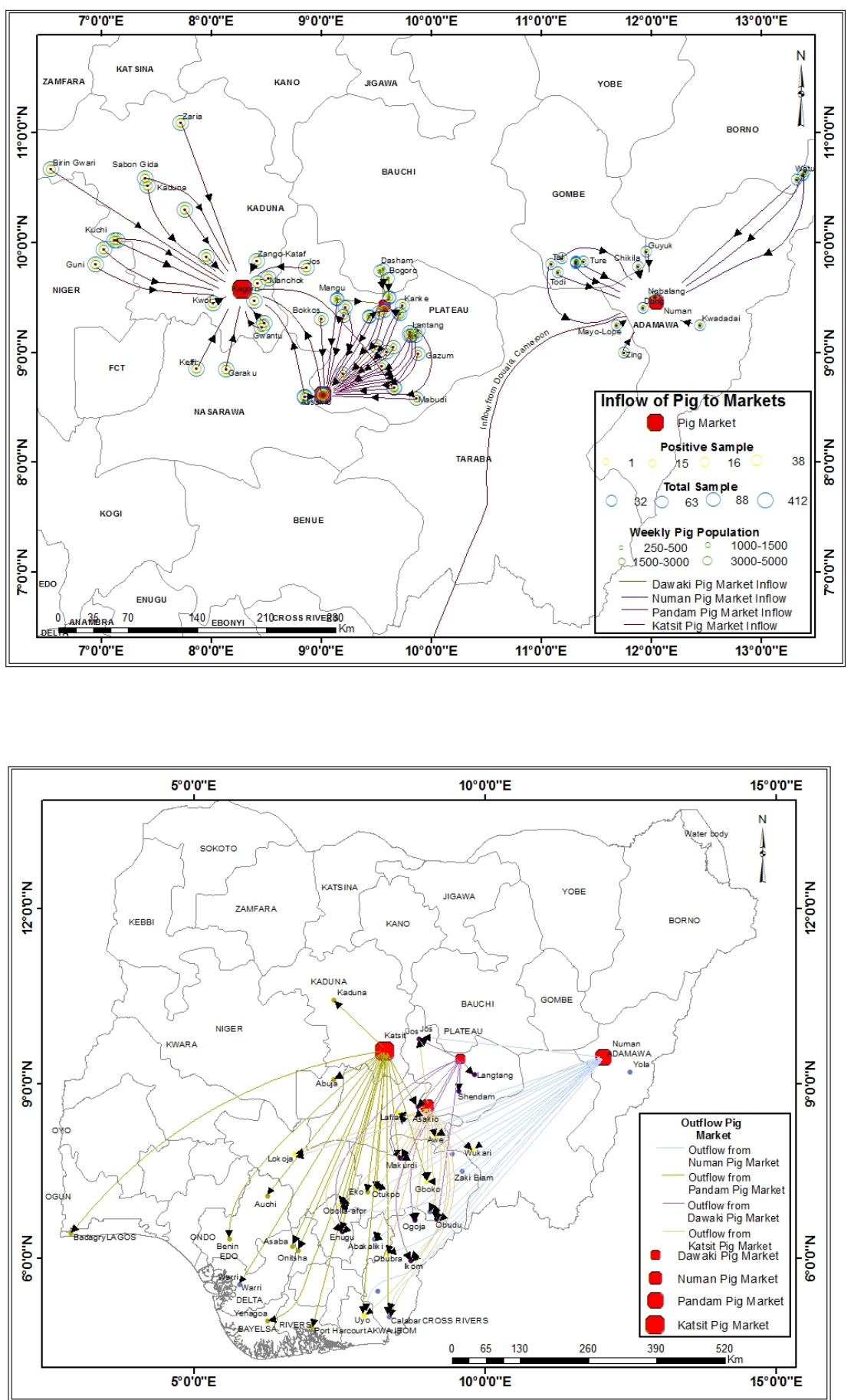

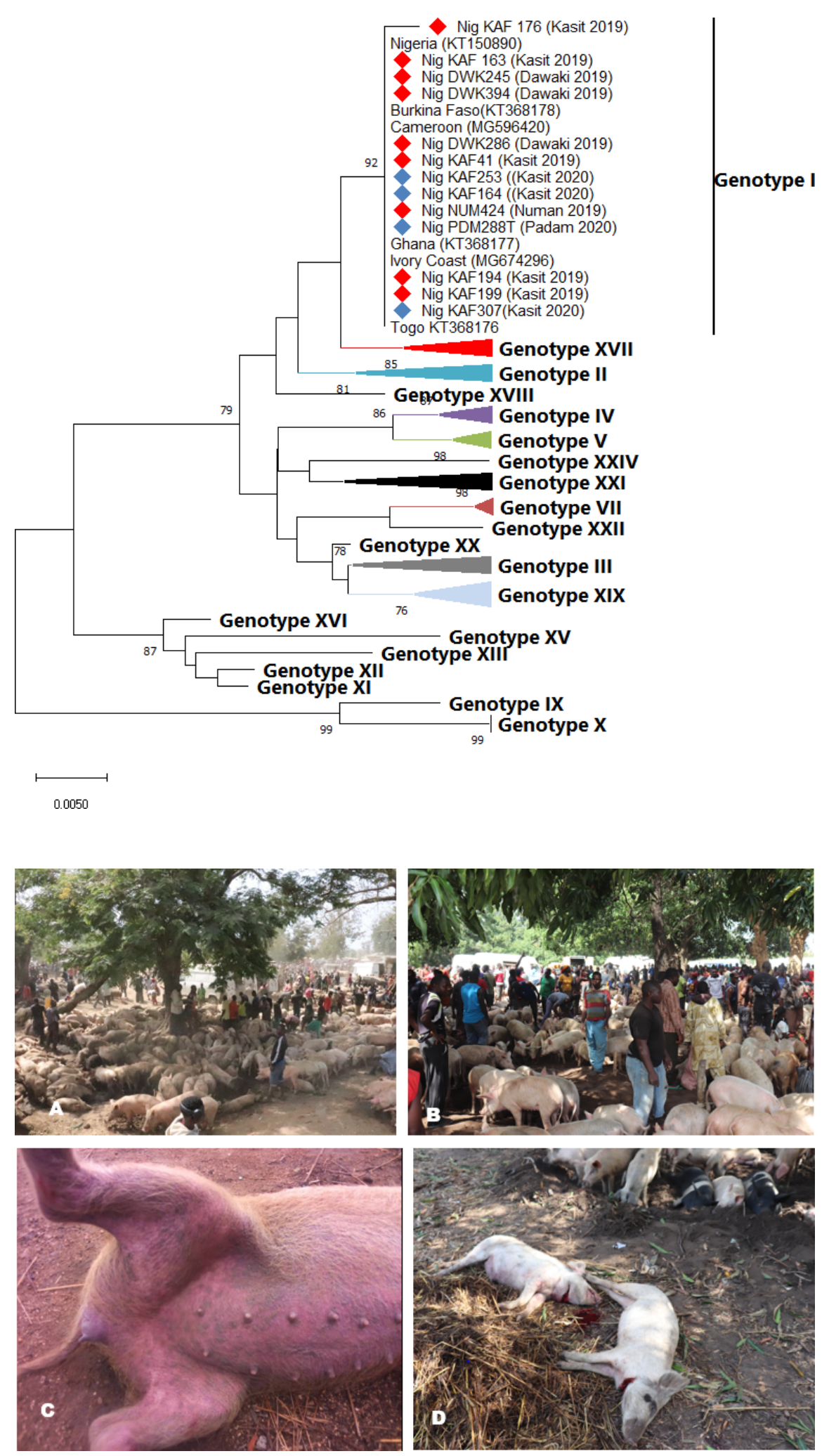